\title{
Thrills in response to music and other stimuli
}

\author{
AVRAM GOLDSTEIN \\ Stanford University, Stanford, California 94305 \\ and Addiction Research Foundation, 701 Welch Road, Palo Alto, California 94304
}

\begin{abstract}
Approximately half of those surveyed experience characteristic tingling sensations (thrills) when exposed to emotionally arousing stimuli. Music was especially effective as a stimulus. Thrills evoked by music were quantitated according to self-reports on frequency, intensity, and duration. In preliminary experiments with naloxone, an opiate receptor antagonist, thrills were attenuated in some subjects.
\end{abstract}

Emotionally arousing experiences are often called "thrilling". A thrill is "a subtle nervous tremor caused by intense emotion or excitement (as pleasure, fear, etc.), producing a slight shudder or tingling through the body..." (Oxford English Dictionary, 1933). This phenomenon, so far as I am aware, has not hitherto been the subject of scientific investigation.

My interest in thrills was stimulated by Dr. Ralph Hansteen in the course of experiments with naloxone, an opiate antagonist (Goldstein \& Hansteen, 1977). If thrills could be produced and measured reliably, it might be possible to test whether or not endogenous opioid peptides (Goldstein, 1976) play a role in this emotional response. In my own experience, music is a potent stimulus for thrills. I therefore carried out questionnaire surveys to find out if the phenomenon of thrills is a rare or a common one, how the thrills are described by those who experience them, and by what kinds of stimuli the thrills are evoked.

I also used music to bring the thrills under some kind of experimental control. To test the hypothesis that thrills, like other emotional responses, may be mediated in some manner by endorphins (Goldstein, 1976), I carried out preliminary experiments attempting to block them with naloxone, an opiate receptor antagonist.

\section{METHODS}

\section{Questionnaire Surveys}

Questionnaires were sent out to three groups: (a) employees of the Addiction Research Foundation, numbering 45, from whom

I acknowledge the contributions of the following, who served as subjects: B. A. Judson, B. J. Trueblood, J. P. Zenk, M. Krebser, M. J. Hayes, L. P. Crouse, L. M. Ortiz y Pino, J. Kehnle, E. L. Murphy, L. F. Cobb, E. L. Nelson, D. D. Dimmitt, L. Epstein, D. B. Powers, and C. U. Jones. Dr. B. W. Brown, Jr., gave valuable advice and criticism concerning the data analysis. Naloxone hydrochloride and placebo ampuls were the gift of Endo Laboratories, Inc. This investigation was supported by Grant DA-1199 from the National Institute on Drug Abuse. It was authorized under IND-14,673 (Food and Drug Administration), and by the Human Subjects Committee of the Addiction Research Foundation. a $100 \%$ response was obtained; (b) all medical students at Stanford University, numbering 387 , of whom $30 \%$ responded; (c) all music students at Stanford University, numbering 126, of whom $70 \%$ responded. Initially (Groups a and b), the questionnaire was largely unstructured, with descriptive prose requested. On the basis of these responses, a standardized checklist was developed for Group c. I sought the following kinds of information about thrills: (1) Are they ever experienced and, if so, how often? (2) What kinds of stimuli elicit them? (3) In what parts of the body do they begin? (4) To what parts of the body do they spread? (5) What do they feel like?

\section{Experiments on Thrills Elicited by Music}

Volunteer subjects who gave informed consent listened through earphones to music of their own choice on stereophonic tape, sitting in a quiet, darkened room. Raising one finger signified a definite thrill of lowest intensity and localized, two fingers a stronger thrill with some spread, three fingers a maximum intensity thrill spreading widely to distant parts of the body. Duration was indicated by the length of time the finger(s) remained raised. I sat nearby, wearing earphones too, and recording the time, intensity, and duration of each thrill episode to the nearest second.

In preliminary experiments, saline or naloxone hydrochloride $(10 \mathrm{mg} / \mathrm{ml})$ was injected intravenously in a double-blind manner, between two auditions of the same musical passage. Thrill scores, based on frequency, intensity, and duration, were compared for the preinjection and postinjection audition.

\section{RESULTS}

\section{Questionnaire Surveys}

Table 1 gives the prevalence of thrills in the three groups surveyed. Males and females did not differ, so the data from both are pooled. Those who experience thrills were probably most likely to respond to the questionnaire, but even based on the total target population, thrills are seen to be a fairly common phenomenon.

By far the most frequent site of origin of thrills is the area of the upper spine and back of the neck (67\% and $62 \%$ of respondents). Shoulders, lower spine, and scalp were also mentioned by about $25 \%$. Spreading occurs typically in a radiating or sweeping pattern, upward over the scalp $(65 \%)$ and face $(39 \%)$, outward over the shoulders $(61 \%)$ and arms $(63 \%)$, down the spine $(52 \%)$, and sweeping forward to in- 
Table 1

Prevalence of Thrills in the Three Target Populations as Indicated by Responses to the Question: "Do you ever get these thrills?"

\begin{tabular}{cccccc}
\hline & & & & \multicolumn{3}{c}{$\begin{array}{c}\text { "Yes" as a Percent of } \\
\text { Respon- } \\
\text { Group }\end{array}$} & $\begin{array}{c}\text { Target } \\
\text { Population }\end{array}$ & $\begin{array}{c}\text { Respon- } \\
\text { dents }\end{array}$ & "Yes" & $\begin{array}{c}\text { Population } \\
\text { dents }\end{array}$ \\
\hline a & 45 & 45 & 24 & 53 & 53 \\
b & 387 & 116 & 93 & 80 & 24 \\
c & 126 & 88 & 79 & 90 & 63 \\
\hline
\end{tabular}

Note-For a description of the groups, see Methods.

volve the chest $(34 \%)$, genital region $(29 \%)$, thighs $(30 \%)$, and legs $(28 \%)$. Mild thrills were usually described as transient $(1$ to $5 \mathrm{sec})$ and localized at the point of origin, while intense thrills (associated with intense emotions) spread and were of longer duration.

There was agreement about what a thrill feels like. It is a chill, shudder, tingling, or tickling. It may be accompanied by a feeling of "hair standing on end" or "goose bumps" on the arms. Thrills are invariably associated with sudden changes in mood or emotion. They may be accompanied by sighing, palpitation, tension of the jaw and facial muscles, a feeling of "lump in the throat," or incipient weeping. Some respondents noted a certain similarity of thrills to orgasm, but with many reservations concerning quality and intensity. Thrills were stated to be pleasurable by $76 \%$ and $91 \%$ of respondents in Groups b and c, respectively.

An estimate of how often thrills are experienced was obtained from Group c, who were asked: "When did you last experience a thrill?" Responses were: today, $19 \%$; today or yesterday, $38 \%$; within the past 7 days, $59 \%$. Thus, thrills occur, on the average, about once or twice a week in this group of music students.

What are the typical circumstances that cause thrills? For Groups $a$ and $b$, the unstructured responses were classified according to their content. Thrills occur most commonly in response to music (primarily to musical passages with special emotional meaning for a person), but music was not the sole stimulus in anyone. In Group $b$, for example, the mean number of different stimuli mentioned was 2.7 per respondent. Group c was presented with a structured checklist; Table 2 represents the results, which are consistent with those from the spontaneous replies of Groups $a$ and $b$. Respondents were invited to write on blank lines "any other things that cause thrills frequently for you, but are not already on the list." This elicited 31 additional mentions, each by no more than a few people, and all of them falling into the same broad categories already noted.

In summary, the typical stimulus that elicits a thrill is a confrontation with an emotionally stirring situation or event, such as a natural scene of transcendent beauty, a magnificent work of art or drama, a musical passage, a poignant personal encounter, a rousing speech, or a sudden intellectual insight. Even imagining these stimuli can be effective. In people who experience thrills, there is invariably more than one kind of effective stimulus. The single generalization that seems to apply is that the thrills are associated with emotional arousal.

\section{Experiments on Thrills Elicited by Music}

Results of a typical session are shown in Figure 1. The general similarity of the records for the two auditions (before and after a saline injection) is evident. To me, listening, the pattern corresponded quite obviously to the dramatic peaks and valleys of the music. A particular subject usually gives the same pattern at each listening to the same passage. On different days, however, there may be large differences in the number and intensities of the thrills, although the general pattern usually remains the same. Another subject's responses to the same music may be completely different. Evidently, the emotional content is perceived differently by different people. Often, subjects told me, what makes a certain musical passage able to elicit thrills is some association with an emotionally charged event or a particular person in the subject's past, as though the music had become a conditioned stimulus for the emotional response.

In 3 of 10 subjects, thrills were significantly attenuated by naloxone as compared with saline. For 19 , 10 , and 9 sessions (with approximately. equal numbers of naloxone and saline injections), the data on these three subjects yielded one-tailed $p$ values of $.0015, .032$, and .038 , respectively. As shown by

Table 2

Frequencies of Stimuli that Cause Thrills

\begin{tabular}{ll}
\hline \multicolumn{1}{c}{ Item } & $\%$ \\
\hline a. Scene in a movie, play, ballet, or book & 92 \\
b. Great beauty in nature or art & 87 \\
c. Musical passages & 96 \\
d. Seeing or reading about something heroic & 59 \\
e. Nostalgic moments & 70 \\
f. Moments of inspiration & 65 \\
g. Physical contact with another person & 78 \\
h. Something momentous and unexpected happening & 63 \\
i. Sudden insight, understanding, solution of a problem & 57 \\
j. Sexual activity & 70 \\
k. Climactic moments in opera & 72 \\
l. Particular moments at a sports event & 52 \\
m. Watching emotional interactions between other people & 67 \\
n. Success in a competitive endeavor & 49 \\
o. Parades & 26 \\
p. Viewing a beautiful painting, photograph, or sculpture & 67 \\
q. Physical exercise & 36 \\
r. Particular fragrances & 39 \\
\hline
\end{tabular}

Note-Data are for Group $c$ as percents of respondents (\%) who ever experience thrills in response to each stimulus. Questionnaire instructions: 'Indicate by placing the appropriate number in the box next to each item, how readily that item causes thrills for you. 1 = not at all, 2 =rarely, $3=$ sometimes, $4=$ frequently." 

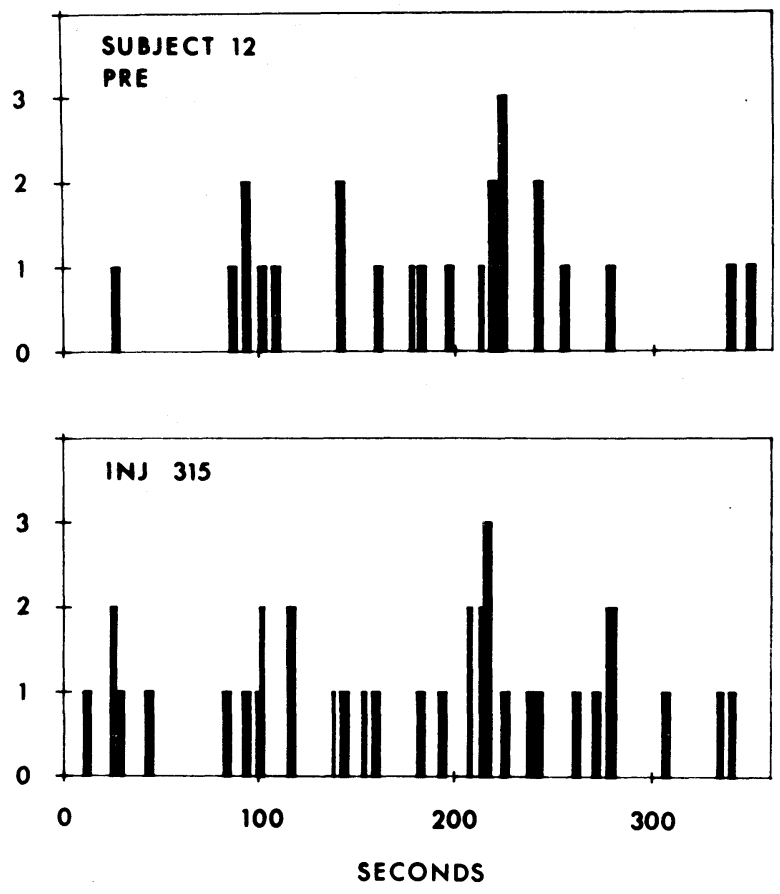

Figure 1. Thrills elicited by music. Typical pattern, Subject 12. Music was a 6-min passage from Gounod's Faust, Act 3. Thrill intensity $(1,2,3)$ is shown on $y$-axis, time on $x$-axis. Width of bar represents duration of thrill. Upper record: initial audition. Lower record: same passage repeated, $15 \mathrm{~min}$ after double-blind i.v. injection of saline (code 315).

Fisher (1978, p. 100), the null hypothesis in this case-that naloxone had no effect in any subject-can be rejected at $p<.01$. We have shown elsewhere that double-blind injections of naloxone can not be distinguished from saline by any interoceptive cues (Grevert \& Goldstein, 1977, 1978). Further experiments of this kind are in progress.

\section{DISCUSSION}

I have described the phenomenon of thrills, their prevalence, their characteristics, and the stimuli that elicit them. About half of those surveyed experience thrills as so commonplace an accompaniment of strong emotion that they presume them to be universal. Yet, to the others, the phenomenon is entirely unknown, so that its very existence is regarded with skepticism. A typical thrill is described as a slight shudder, chill, or tingling sensation, usually localized at the back of the neck, and fleeting. A more intense thrill lasts longer, and may spread from the point of origin, up over the scalp, forward over the face, downward along the spine, and forward over the chest, abdomen, thighs, and legs. It may be accompanied by visible gooseflesh (piloerection), especially on the arms. Incipient weeping may occur, and sighing, together with a feeling of a "lump in the throat."
That thrills, with their obvious involvement of the autonomic nervous system, are a manifestation of emotion has long been recognized in language and literature. To say something is "thrilling" means it stirs the emotions, but a "thrill" is also a physical vibration.

Any kind of experience that arouses the emotions can elicit thrills in those who are susceptible. The common element appears to be a confrontation with something of extraordinary beauty or profound and moving significance. Music (of the right kind) is very often effective. It is curious that evolution selected for and conserved this curious ability to feel a slight shudder when we are emotionally aroused.

Since music evokes thrills so effectively, it was surprising to find only passing reference to the phenomenon in the literature of psychology or of music. Students of the relationship of music to the emotions have been concerned primarily with discovering what qualities of music make it seem pleasant or unpleasant, exciting or tedious, and what timbres, pitches, harmonies, dissonances, and cadences evoke various mood states or can be employed therapeutically (Critchley \& Henson, 1977; Discrens, 1926; Meyer, 1956; Schoen, 1927; Seashore, 1936, 1938; Smith, 1976; Wedin, 1972). Clynes (1978) comes closest to recognizing thrills evoked by music, but he fails to describe the phenomenon explicitly.

The localized origin and subsequent spread of the thrills to contiguous parts of the body requires comment. Although the sensation of thrill is perceived at the surface of the body (e.g., at the back of the neck), it must be assumed that this is a referred sensation from a central neural focus. I imagine, therefore, that the perceived thrill reflects a spreading electrical activity in some brain area with somatotopic organization, and with neural links to the limbic system and to central autonomic regulation. Since the thrills are usually felt on both sides of the body, the area must have bilateral representation of sensory inputs (Mountcastle, 1974). The amygdala is a possible candidate because of its role in emotional functions, autonomic discharge, and discrimination of sensory modalities (Pribram, 1977).

That an emotional response involving the autonomic nervous system might be mediated by the recently discovered opioid peptides (endorphins) seemed an obvious conjecture, given the association of opiate receptors with the limbic system and the euphorigenic effects of the opiates (Goldstein, 1976). Preliminary experiments suggest that in some people thrills elicited by music may be attenuated by naloxone, a specific antagonist at the opiate (endorphin) receptors.

\section{REFERENCES}

Clynes, M. Sentics: The touch of emotions. Garden City, N.Y: Anchor Press/Doubleday, 1978. 
Critchley, M., \& Henson, R. A. (Eds.). Music and the brain. Springfield, Ill: Thomas, 1977.

Discrens, C. M. The influence of music on behavior. Princeton, N.J: Princeton University Press, 1926.

Fisher, R. A. Statistical methods for research workers (11 th ed.). Edinburgh: Oliver \& Boyd, 1978.

Goldstein, A. Opioid peptides (endorphins) in pituitary and brain. Science, 1976, 193, 1081-1086.

Goldstein, A., \& Hansteen, R. W. Evidence against involvement of endorphins in sexual arousal and orgasm in the human male. Archives of General Psychiatry, 1977, 34, 1179-1180.

Grevert, P., \& Goldstein, A. Effects of naloxone on experimentally induced ischemic pain and on mood in human subjects. Proceedings of the National Academy of Sciences, 1977, 74, 1291-1294.

Grevert, P., \& Goldstein, A. Endorphins: Naloxone fails to alter experimental pain or mood in humans. Science, 1978, 199, 1093-1095.

Meyer, L. B. Emotion and meaning in music. Chicago: University of Chicago Press, 1956.

Mountcastle, V. B. Neural mechanisms in somesthesia. In V. B. Mountcastle (Ed.), Medical physiology (Vol. 1). St. Louis: Mosby, 1974.
Oxford English Dictionary. Oxford: University Press, 1933.

Pribram, K. H. Peptides and protocritic processes. In L. H. Miller, C. A. Sandman, \& A. J. Kastin (Eds.), Neuropeptide influences on the brain and behavior. New York: Raven Press, 1977.

Schoеn, M. The effects of music. New York: Harcourt-Brace, 1927.

Seashore, C. E. Studies in the psychology of music (Vol. 3). Iowa City: University Press, 1936.

Seashore, C. E. Psychology of music. New York: McGraw-Hill, 1938.

Sмiтh, C. A. Effects of stimulative and sedative music in cognitive and emotional components of anxiety. Psychological Reports, 1976, 38, 1187-1193.

Wedin, L. A multidimensional study of the perceptual-emotional qualities in music. Scandinavian Journal of Physiology, 1972, 13, 241-257.

(Received for publication December 27, 1979; revision accepted February 13, 1980.) 